\title{
Chemical Characterization of Oleaster, Olea europaea var. sylvestris (Mill.) Lehr., Oils from Different Locations of Northeast Portugal
}

\author{
Nuno Rodrigues ${ }^{1}$, Teresa Pinho ${ }^{2}$, Susana Casal ${ }^{2}{ }^{\circledR}$, António M. Peres ${ }^{1}\left(\mathbb{D}\right.$, Paula Baptista $^{1}{ }^{1}$ \\ and José Alberto Pereira $1, *$ (i) \\ 1 Centro de Investigação de Montanha (CIMO), ESA, Instituto Politécnico de Bragança, Campus de Santa \\ Apolónia, 5300-253 Bragança, Portugal; nunorodrigues@ipb.pt (N.R.); peres@ipb.pt (A.M.P.); \\ pbaptista@ipb.pt (P.B.) \\ 2 LAQV/REQUIMTE, Laboratory of Bromatology and Hydrology, Faculty of Pharmacy, University of Porto, \\ Rua de Jorge Viterbo Ferreira, 228, 4050-313 Porto, Portugal; teresapinho847@gmail.com (T.P.); \\ sucasal@ff.up.pt (S.C.) \\ * Correspondence: jpereira@ipb.pt; Tel.: +351-273303277; Fax: +35122-273325405
}

Received: 26 August 2020; Accepted: 14 September 2020; Published: 15 September 2020

\begin{abstract}
Oleaster (Olea europaea var. sylvestris), or the wild olive tree, has great interest as a source of genetic material for olive breeding programs. Nevertheless, information about its oil composition is scarce. In the present work, the characterization of oleaster fruit morphology and oil chemical composition from three different tree populations in Northeastern Portugal (Moncorvo, Alijó and Vila Nova de Foz Côa) was performed. The three studied populations presented some morphological differences in the fruits, but similar oil chemical composition. Oleic acid (68.9-70.6\%) was the most abundant fatty acid. High variability was observed in total tocopherol content, ranging between 263 and $503 \mathrm{mg} / \mathrm{kg}$. Additionally, high amounts of total sterols were found, from 1742 to $2198 \mathrm{mg} / \mathrm{kg}$ of oil. A rich composition in phenols was found with 14 phenolic compounds identified. The evaluated parameters for oleander oils allowed discriminating the oils according to the geographical origin and were consistent with those commonly found in olive oil, showing that they are particularly rich in antioxidants and can be exploited in breeding programs to increase the amounts of bioactive compounds in cultivated oils.
\end{abstract}

Keywords: wild olive tree; genetic resources; valorization; bioactive compounds

\section{Introduction}

The olive tree, Olea europaea subsp. europaea, is a typical species of the Mediterranean basin, traditionally limited to Europe and Africa [1]. This crop was one of the first to be domesticated, apparently in the Middle East, from where it spread to the west of the Mediterranean basin with human migrations [2]. During this process, not all plants showed good adaptation to domestication, or characteristics considered of interest for selection, originating two varieties of O. europaea: the cultivated forms, the olive tree (O. europaea subsp. europaea var. europaea), and the wild forms, the oleasters (O. europaea subsp. europaea var. sylvestris) [1,3-5]. Thus, cultivated olive tree and oleaster are considered by botanists two varieties of $O$. europaea subsp. europaea [1]. The main phenotypic difference between both is that the flesh is thicker and the fruits are larger in most cultivated varieties [1]. Nevertheless, other differences could be mentioned: oleasters have smaller leaves, prickly juvenile shoots in the lower branches, fruits with a lower ratio of pulp/endocarp and lower fat content, a longer juvenile stage and a greater ability to survive in harsh environments [6,7]. 
Several studies have shown that olive oil obtained from cultured olive trees have beneficial effects on human health, with beneficial biological properties to the consumer [8]. Motivated by this recognition, together with its exquisite sensorial attributes, the cultivated olive tree is now distributed throughout the world, with particular success in areas with a climate similar to that of the Mediterranean region [7]. It is now one of the most consumed virgin edible oil in the world due to its good characteristics, such as its pleasant aroma and taste, and its high resistance to oxidation [7]. As to O. europaea subsp. europaea var. sylvestris, although not a cultivated species, it has been studied mainly due to its key role in the development and selection of new olive cultivars, with a recognized capacity for adaptation and survival and superior olive oil quality [9].

Olives obtained from the oleaster represent a distinctive element of the Mediterranean flora [10]. However, information regarding the oil extracted from these wild olive trees is scarce, in particular its composition $[3,11]$. Some studies reported that oleaster oil has higher levels of antioxidants and oleic acid than the oil obtained from cultivated olive trees [12], highlighting the high potential of oleaster oil as a phytochemicals source, and as a possible alternative food and resource to improve the quality of olive oil [7].

In Portugal, oleaster is commonly distributed throughout the country, mainly in the central and southern regions. In the north region, although the olive tree in the cultivated form is dominant, specimens of oleaster can still be found in zones near important rivers like Douro, Sabor and Côa, not being used as fruits producers. Thus, in this context, the aim of the present work was to characterize the oil obtained by fruits of three oleaster populations from different municipalities located in the north of Portugal, Alijó, Moncorvo and Vila Nova de Foz Côa (VNFC), in terms of its composition in fatty acids, individual phenolic content, tocopherol and sterol content, to evaluate the possibility of using oleaster trees in breeding programs and also its oil as an innovative food rich in bioactive compounds.

\section{Materials and Methods}

\subsection{Sampling}

Three different locations where oleaster (O. europaea L. ssp. sylvestris (Miller) Lehr synonym of O. europaea L. ssp. oleaster (Hoffmanns. and Link Negodi) plants exist were chosen, being located in three municipalities of the northeast of Portugal, namely: Moncorvo (Foz do Sabor, N 41 ${ }^{\circ} 11^{\prime} 57.498^{\prime \prime}$; W $7^{\circ} 5^{\prime} 46.302^{\prime \prime}$ ), Vila Nova de Foz Côa (VNFC) (Pocinho, N 41 ${ }^{\circ} 8^{\prime} 6.058^{\prime \prime}$; W $7^{\circ} 7^{\prime} 54.005^{\prime \prime}$ ) and Alijó (Romaneira, N 41 $12^{\prime} 7.045^{\prime \prime} ; \mathrm{W} 7^{\circ} 29^{\prime} 25.444^{\prime \prime}$ ). In each location, four adult oleaster plants with fruitification were randomly selected considering each plant as an independent tree. In November 2016, from each plant, roughly two kilograms of fruits were manually picked. To overcome the influence of the maturation stage on oil composition, drupes were harvested when the fruit epidermis changed from purple in more than half the olive (ripening stage- R.S.3.0) to completely purple and white pulp (R.S. 4.0). Fruits were visually examined, being discarded damaged fruits or those that had been attacked by pests or diseases. From each olive sample, a sub-sample of 40 fruits was taken for morphological characterization and the remaining fruits were processed for oil extraction. All fruit samples were evaluated at a morphological level, using biometric parameters of the fruit and the endocarp of the same fruit according to International Union for the Protection of New Varieties of Plants (UPOV) guidelines for Olea europaea [13]. The following parameters were evaluated: weight (g), length (mm), maximum diameter $(\mathrm{mm})$, shape, symmetry in A and B positions, position of maximum transverse diameter at $B$ position, apex in A position, base, nipple, number and dimension of the lenticules, colour at full maturity, rugosity of the surface, number of grooves on basal end and distribution of grooves on basal end. Fruit shape was calculated from the ratio between the maximum length/width, which may lead to a classification of the fruit shape as spherical (length/width ratio $<1.25$ ), ovoid $(1.25 \leq$ length/width ratio $\leq 1.45)$ or elongated (length/width ratio $>1.45)$.

Oil was extracted from fruits during the first $24 \mathrm{~h}$ after harvest, in a pilot plant with an Abencor analyzer (Comercial Abengoa S.A., Seville, Spain), which included a mill, a thermobeater where 
malaxation takes place at a controlled temperature, and a centrifuge. Fruits were milled, then around $700 \mathrm{~g}$ of homogenized paste was transferred to the thermobeater unit $(20 \mathrm{~min})$ for malaxation, which was heated using a thermostatic water bath at $25^{\circ} \mathrm{C}$. During the last 5 min of each malaxation, $100 \mathrm{~mL}$ of water at $25^{\circ} \mathrm{C}$ were added to enhance the oil separation. The mixture was centrifuged, decanted, and the oil collected. After that, the oils were filtered (Whatman paper no. 4) over anhydrous sodium sulphate to remove the solid particles and residual water. The oils then were stored in $100 \mathrm{~mL}$ dark glass bottles and protected from light exposition, at room temperature. All the assays were performed in triplicate within two months after extraction.

\subsection{Fatty Acids Composition}

Fatty acids were assessed as their methyl esters after cold alkaline transesterification with methanolic potassium hydroxide solution [14] and extraction with n-heptane. The fatty acid profile was established using a Chrompack CP 9001 chromatograph, which comprised a split-splitless injector, a FID detector, an autosampler Chrompack CP-9050 and a fused silica Select FAME capillary column (50 $\mathrm{m} \times 0.25 \mathrm{~mm}$ i.d.; Varian, Palo Alto, CA, USA). The carrier gas was helium at an internal pressure of $110 \mathrm{kPa}$. The detector temperature was $270{ }^{\circ} \mathrm{C}$ and the injector was kept at $250{ }^{\circ} \mathrm{C}$. A 1:50 split ratio was used being injected $1 \mu \mathrm{L}$. The fatty acids contents were quantified in relative percentage, calculated by internal normalization of the chromatographic peak area eluting between myristic and lignoceric methyl esters. A control sample (olive oil, Supelco, Bellefonte, PA, USA) and a fatty acids methyl esters standard mixture (Supelco 37 FAME Mix) were used for identification and calibration purposes (Sigma, Madrid, Spain).

\subsection{Tocopherols Composition}

Tocopherols were assessed following the ISO 9936 [15], with some modifications [16]. Tocopherols standards ( $\alpha$-, $\beta$ - and $\gamma$-) were purchased from Sigma (Spain), and 2-methyl-2-(4,8,12-trimethyltridecyl) chroman-6-ol (tocol), used as the internal standard, was from Matreya Inc. (Pleasant Gap, PA, USA). Filtered olive oil (50 mg) plus $10 \mu \mathrm{L}$ of the internal standard solution (tocol, $100 \mu \mathrm{g} / \mathrm{mL}$ prepared with n-hexane) were mixed and then centrifuged for $5 \mathrm{~min}$ at 13,000 rpm, being the obtained supernatant analysed by high-performance liquid chromatography (HPLC). A Jasco integrated system (Tokyo, Japan) was used, comprising a Jasco LC-NetII/ADC data unit, a PU-1580 Intelligent Pump and a FP-920 fluorescence detector $(\lambda \mathrm{exc}=290 \mathrm{~nm}$ and $\lambda \mathrm{em}=330 \mathrm{~nm})$. For the chromatographic separation, a SupelcosilTM LC-SI column $(3 \mu \mathrm{m}) 75 \times 3.0 \mathrm{~mm}$ (Supelco, Bellefonte, PA, USA) at $23^{\circ} \mathrm{C}$ was used. The eluent was a mixture of $\mathrm{n}$-hexane and 1,4-dioxane (97.5:2.5), at a flow rate of $0.7 \mathrm{~mL} / \mathrm{min}$. Data were analysed with the ChromNAV Control Center-JASCO Chromatography Data Station (Japan). The compounds were identified using standards, considering the co-elution retention time and according to their UV spectra. Quantification was based on the internal standard method, using the fluorescence signal response and individual calibration curves for each tocopherol. Total vitamin E was quantified as the sum of the individual tocopherol contents.

\subsection{Sterols Composition}

The oils' sterol contents were determined according to the official European analysis methods [14]. Briefly, oils were saponified with an ethanolic potassium hydroxide solution with dehydrocholesterol (internal standard), being the extracted unsaponifiables concentrated and then separated on silica gel plates. The sterol fraction was extracted, silylated and analysed on a GC-FID Thermo Finnigan (Milan, Italy), using a Zebron ZB-5HT Inferno (30 $\mathrm{m} \times 0.25 \mathrm{~mm} \times 0.25 \mu \mathrm{L}$; Phenomenex, Torrance, CA, USA), with a temperature program from $250{ }^{\circ} \mathrm{C}$ to $280{ }^{\circ} \mathrm{C}$. The carrier gas was helium (Gasin, Porto, Portugal) at a flow rate of $0.6 \mathrm{~mL} / \mathrm{min}$. Individual sterols were quantified in relative percentage and the total sterols amounts in $\mathrm{mg} / \mathrm{kg}$, as internal standard equivalents. Identification was accomplished based on the retention times of commercial standards (Sigma-Aldrich, Darmstadt, Germany) with the exception of $\Delta 5$-avenasterol and $\Delta 7$-stigmastenol, tentatively identified 
by comparing with literature references. Apparent $\beta$-sistosterol, an important quality indicator, was quantified as the sum of $\Delta 5$-avenasterol, clerosterol and $\beta$-sitosterol, following EEC regulation.

\subsection{Phenolic Compounds}

The oils' phenolic compounds were extracted according to the guidelines of the International Olive Council (COI) [17], with minor modifications. Briefly, the phenolic compounds were extracted with methanol/water solution (80:20, $v / v)$, in the presence of syringic acid as internal standard, followed by addition of $n$-hexane to the methanolic solution for removal of fat remains. The solution was concentrated under a gentle nitrogen stream $\left(40^{\circ} \mathrm{C}\right)$ and analysed by HPLC with a diode array detector. A C18 reversed-phase column (Kinetex C18 $2.6 \mu \mathrm{m} 100 \AA \AA, 100 \times 3.00 \mathrm{~mm}$, Phenomenex) at $35^{\circ} \mathrm{C}$ was used for separation, being applied a gradient of water and acetonitrile, both with $0.1 \%$ of formic acid, at a flow rate of $0.8 \mathrm{~mL} / \mathrm{min}$. Peaks were identified by comparing the retention times and UV-VIS spectra (200-600 nm) with those of pure standards (tyrosol, hydroxytyrosol, vanillic acid, ferulic acid, o-coumaric acid, luteolin, cinnamic acid, apigenin and oleuropein from several suppliers). Ligstroside derivatives tentative identification was oriented by the COI method and available literature [17-20]. For quantification, UV-VIS detection wavelengths of $280 \mathrm{~nm}$ (for simple phenols, vanillic acid, vanillin and secoiridoids), $325 \mathrm{~nm}$ (for coumaric and ferulic acids) and $365 \mathrm{~nm}$ (for flavonoids) were used. According to the COI guidelines, results were expressed as $\mathrm{mg}$ of tyrosol equivalents per $\mathrm{kg}$ of oil for each individual compound, being the total phenols content calculated as the sum of all individual compounds quantified on the same basis.

\subsection{Statistical Analysis}

The possible statistical significant effect of the sampling geographical location on the physicochemical and sensory parameters of the oils was evaluated using the one-way analysis of variance (one-way ANOVA) at a significance level of $5 \%$. When a significant statistical effect was observed ( $p$-value $<0.05$ ), the post-hoc multi-comparison Tukey's test was further used to identify the levels of each effect that were responsible for the detected significant effect.

Linear discriminant analysis (LDA), a supervised multivariate pattern recognition technique, coupled with the simulated annealing (SA) variable selection algorithm was used to verify if the physicochemical profiles of the oils could be used to discriminate the three different geographical grown locations of the oleaster trees. The SA algorithm allows identifying the non-redundant physicochemical parameters with the highest discrimination capability. For LDA, the values of the different parameters were centred and scaled minimizing data variability. The quality of the discrimination performance was assessed considering the correct classification rate for the original grouped data and the internal cross-validation leave-one-out procedure (LOO-CV). The classification performance of the LDA-SA model was also graphically evaluated using 2-D plot of the two main discriminant functions, being plotted the class membership boundary lines established using the posterior probabilities, computed using Bayes' theorem (which enables controlling of overfitting issues) [21]. The statistical analysis was performed using the [22-24] and MASS [25] packages of the open source statistical program R (version 2.15.1), at a 5\% significance level.

\section{Results and Discussions}

\subsection{Morphological Characterization}

The morphological characterization of the oleaster fruits and endocarps was performed according to UPOV parameters (Table 1). Fruit weight, length and width were all significantly higher in the Alijó population ( $p$-value $<0.0001$ ), and usually lower in the VNFC population (Table 1). Variations of fruit shape were observed, from ovoid (fruits collected at Alijó location) to elongated ones (fruits collected at Moncorvo and VNFC locations). 
Table 1. Biometric and morphological characteristics of fruit and endocarp (mean \pm standard deviation), in percentage (\%) of occurrence, of oleaster fruits obtained.

\begin{tabular}{|c|c|c|c|c|c|c|c|c|c|c|c|c|}
\hline Olive Fruit. & Weight (g) & Length (mm) & $\begin{array}{l}\text { Width } \\
\text { (mm) }\end{array}$ & Shape & Symm.A & T Diam.B & Apex. & Base & Nipple & $\begin{array}{l}\mathrm{N}^{\circ} \text {. of } \\
\text { Lent. }\end{array}$ & $\begin{array}{l}\text { D. of } \\
\text { Lent. }\end{array}$ & $\begin{array}{c}\text { Total Fat (\% Fresh } \\
\text { Matter) }\end{array}$ \\
\hline Alijó & $1.08 \pm 0.38^{a}$ & $15.20 \pm 2.41^{\mathrm{a}}$ & $\begin{array}{c}10.54 \pm 1.47 \\
a\end{array}$ & $\begin{array}{l}1.45 \pm 0.16^{\mathrm{a}} \\
\text { Ovoid }\end{array}$ & $\begin{array}{c}\text { Asymmetric } \\
66.2 \%\end{array}$ & Central 100.0\% & $\begin{array}{c}\text { Rounded } \\
76.9 \%\end{array}$ & $\begin{array}{c}\text { Rounded } \\
65.0 \%\end{array}$ & $\begin{array}{c}\text { Little } \\
\text { evident } \\
100.0 \%\end{array}$ & $\begin{array}{c}\text { Very } \\
\text { numerous } \\
100.0 \%\end{array}$ & $\begin{array}{c}\text { Small } \\
100.0 \%\end{array}$ & $8.14 \pm 0.57^{a}$ \\
\hline Moncorvo & $0.72 \pm 0.26^{b}$ & $13.35 \pm 1.08^{b}$ & $8.93 \pm 1.51^{b}$ & $\begin{array}{c}1.52 \pm 0.21^{\mathrm{a}} \\
\text { Elongated }\end{array}$ & $\begin{array}{c}\text { Asymmetric } \\
72.5 \%\end{array}$ & Central $100.0 \%$ & $\begin{array}{c}\text { Rounded } \\
75 \%\end{array}$ & $\begin{array}{c}\text { Truncated } \\
81.2 \%\end{array}$ & $\begin{array}{c}\text { Little } \\
\text { evident } \\
100.0 \%\end{array}$ & $\begin{array}{c}\text { Very } \\
\text { numerous } \\
100.0 \%\end{array}$ & $\begin{array}{c}\text { Small } \\
100.0 \%\end{array}$ & $5.75 \pm 0.62^{b}$ \\
\hline $\begin{array}{l}\text { Vila Nova de } \\
\text { Foz Côa }\end{array}$ & $0.59 \pm 0.27^{c}$ & $12.18 \pm 2.04^{\mathrm{c}}$ & $8.33 \pm 1.21^{\mathrm{c}}$ & $\begin{array}{c}1.55 \pm 1.28^{\mathrm{a}} \\
\text { Elongated }\end{array}$ & $\begin{array}{c}\text { Asymmetric } \\
67.5 \%\end{array}$ & Central $100.0 \%$ & $\begin{array}{c}\text { Rounded } \\
100.0 \%\end{array}$ & $\begin{array}{c}\text { Truncate } \\
85.0 \%\end{array}$ & $\begin{array}{c}\text { Little } \\
\text { evident } \\
75.0 \%\end{array}$ & $\begin{array}{c}\text { Very } \\
\text { numerous } \\
75.0 \%\end{array}$ & $\begin{array}{l}\text { Small } \\
83.1 \%\end{array}$ & $6.81 \pm 0.99 \mathrm{a}, \mathrm{b}$ \\
\hline $\begin{array}{c}\text { One-way } \\
\text { ANOVA } \\
(p \text {-value })^{1}\end{array}$ & $<0.0001$ & $<0.0001$ & $<0.0001$ & 0.4390 & - & - & 一 & - & - & - & - & $0.0101-$ \\
\hline Stone & Weight (g) & Length (mm) & $\begin{array}{l}\text { Width } \\
\text { (mm) }\end{array}$ & Shape & Symm.A & Symm.B & T Diam.B & Apex. A & Base & $\begin{array}{c}\text { Rugosity } \\
\text { of surface }\end{array}$ & $\begin{array}{l}\mathrm{N}^{\circ} \text {. of } \\
\text { grooves }\end{array}$ & $\begin{array}{c}\text { Distribution of } \\
\text { Grooves }\end{array}$ \\
\hline Alijó & $0.32 \pm 0.09^{a}$ & $12.47 \pm 2.06^{\mathrm{a}}$ & $6.47 \pm 0.57^{\mathrm{a}}$ & $\begin{array}{c}1.93 \pm 0.32^{\mathrm{a}} \\
\text { Elliptic }\end{array}$ & $\begin{array}{l}\text { Asymmetric } \\
81.2 \%\end{array}$ & $\begin{array}{c}\text { Weakly asymmetric } \\
8.25 \%\end{array}$ & $\begin{array}{l}\text { Central } \\
81.2 \%\end{array}$ & $\begin{array}{c}\text { Rounded } \\
96.2 \%\end{array}$ & $\begin{array}{c}\text { Acute } \\
58.75 \%\end{array}$ & $\begin{array}{l}\text { Medium } \\
100.0 \%\end{array}$ & $\begin{array}{l}\text { Medium } \\
63.1 \%\end{array}$ & $\begin{array}{l}\text { Grouped around } \\
\text { suture } 90.0 \%\end{array}$ \\
\hline Moncorvo & $0.24 \pm 0.06^{b}$ & $11.20 \pm 0.92^{b}$ & $6.00 \pm 0.76^{b}$ & $\begin{array}{c}1.89 \pm 0.23^{\text {a }} \\
\text { Elliptic }\end{array}$ & $\begin{array}{l}\text { Asymmetric } \\
83.1 \%\end{array}$ & $\begin{array}{c}\text { Weakly asymmetric } \\
87.5 \%\end{array}$ & $\begin{array}{l}\text { Central } \\
89.4 \%\end{array}$ & $\begin{array}{c}\text { Rounded } \\
73.8 \%\end{array}$ & $\begin{array}{c}\text { Rounded } \\
58.1 \%\end{array}$ & $\begin{array}{l}\text { Medium } \\
100.0 \%\end{array}$ & $\begin{array}{c}\text { Low } \\
71.9 \%\end{array}$ & $\begin{array}{c}\text { Grouped around } \\
\text { suture } 81.9 \%\end{array}$ \\
\hline $\begin{array}{l}\text { Vila Nova de } \\
\text { Foz Côa }\end{array}$ & $0.20 \pm 0.08^{c}$ & $9.96 \pm 1.66^{c}$ & $5.63 \pm 0.75^{c}$ & $\begin{array}{l}1.77 \pm 0.20^{b} \\
\text { Ovoid }\end{array}$ & $\begin{array}{c}\text { Asymmetric } \\
74.4 \%\end{array}$ & $\begin{array}{c}\text { Weakly asymmetric } \\
81.2 \%\end{array}$ & $\begin{array}{l}\text { Central } \\
100.0 \%\end{array}$ & $\begin{array}{c}\text { Rounded } \\
75.0 \%\end{array}$ & $\begin{array}{c}\text { Rounded } \\
54.4 \%\end{array}$ & $\begin{array}{l}\text { Medium } \\
100.0 \%\end{array}$ & $\begin{array}{l}\text { Medium } \\
54.4 \%\end{array}$ & $\begin{array}{c}\text { Grouped around } \\
\text { suture } 81.9 \%\end{array}$ \\
\hline $\begin{array}{c}\text { One-way } \\
\text { ANOVA } \\
(p \text {-value })^{1}\end{array}$ & $<0.0001$ & $<0.0001$ & $<0.0001$ & $<0.0001$ & - & - & - & - & - & - & - & - \\
\hline
\end{tabular}

${ }^{1}$ Different lower case letters mean significant statistical differences between the geographical locations, at a 5\% significance level (one-way ANOVA followed by the Tukey's multi-comparison test). 
Compared with cultivated olives from traditional cultivars in Northeastern Portugal, as Cobrançosa, Cordovil, Madural and Negrinha de Freixo, oleaster fruits had, in general, lower fruit measures [26]. As can also be seen in Table 1, all populations produced asymmetric fruits, centred considering the position of maximum transverse diameter at position $\mathrm{B}$, and with a rounded apex. Some differences were obtained for the base parameter, which was either rounded (Alijó location) or truncated (Moncorvo and VNFC locations). For the remaining parameters (presence of nipple, number of lenticules, colour when the fruit reaches the definitive colour when mature) similar ranges were found among the three studied populations (Table 1). Concerning the morphological parameters of the endocarp, the stone weight significantly varied from $0.32 \mathrm{~g}$ (Alijó location) to $0.20 \mathrm{~g}$ (VNFC location) ( $p$-value $<0.0001$ ), similar to the lower results reported by [27] for ancient native olive accessions in Central-Eastern Tunisia populations (i.e., $0.15-1.23$ g, for endocarps) and 3.5-6.0 times lower than the weights usually reported for the endocarps of cultivated olive cultivars of the same Portuguese region [26]. Among the three populations, the lowest values for endocarp length, width and shape were obtained in the VNFC population, being consistently and significantly higher in the Alijó population ( $p$-value $<0.0001)$. For the other parameters the majority of the results were similar for the three locations, with few exceptions (Table 1). Concerning total fat contents, in fresh weight the values significantly varied ( $p$-value $=0.0101)$ between $5.75 \pm 0.62 \%$ in Moncorvo and $8.14 \pm 0.57 \%$ in Aljó (Table 1), lower than the values usually found for olive cultivars.

\subsection{Fatty Acids Composition}

The fatty acid composition of the oils extracted from fruits of different oleaster populations are shown in Table 2. Oleic acid $\left(\mathrm{C}_{18: 1}\right)$ was the major fatty acid, varying from $68.9 \%$ to $70.6 \%$, with highly homogeneous contents between the three populations studied, in opposition to the ranges reported from other geographical regions, like Tunisia, which varied from $47 \%$ to $72 \%$, [5] and $48.4 \%$ to $71.1 \%$ [28], or Algeria, with values ranging from $64.7 \%$ to $76.1 \%$ [7]. Additionally, the oleic acid contents were within the regulated values for virgin olive oil according to Commission Regulation (EEC 2568/91). Palmitic acid $\left(C_{16: 0)}\right.$, ranging from $14.2 \%$ to $15.2 \%$, and linoleic acid $\left(C_{18: 2}\right)$, varying from $7.9 \%$ to $9.9 \%$, were the second and third major fatty acids, also with similar values in the different locations. Once again the content ranges are more homogeneous that those observed by the previously mentioned authors. Nevertheless, some minor fatty acids showed significant differences between the three population: stearic acid $\left(\mathrm{C}_{18: 0}\right)$ was more abundant in the VNFC population than in Alijó and Moncorvo ( $p$-value $=0.0102)$. In opposition, the amounts of linolenic acid $\left(C_{18: 3}\right)$ were significantly higher in the Alijó population ( $p$-value $=0.0098)$, as was eicosenoic acid $\left(C_{20: 1}\right)$. The oleaster oils from Moncorvo were significantly richer in heptadecanoic $\left(C_{17: 0}\right)$ and heptadecenoic $\left(C_{17: 1}\right)$ acids, while VNFC showed the highest amounts of arachidic acid $\left(\mathrm{C}_{20: 0}\right)$ (Table 2$)$.

The sum of saturated fatty acids (SFA), monounsaturated fatty acids (MUFA) and polyunsaturated fatty acids (PUFA) had no significant differences between the different populations (Table 2). The highest fraction as expected were the MUFA, varying from $71.9 \%$ (Alijó population) to $73.0 \%$ (Moncorvo population), followed by SFA (16.9-18.2\%) and PUFA (8.8-10.9\%). When comparing these results with the fatty acid composition of Portuguese traditional cultivars (cvs. Cobrançosa, Madural and Verdeal Transmontana) [29], similar profiles could be found. Additionally, all the values are in agreement with the legal maximum values established by the Commission Regulation (EEC 2568/91) for olive oil. As mentioned before, in the present work the variation in fatty acid profile showed high homogeneity between samples within and between locations, in disagreement with the literature for oleaster oils $[5,7,28]$. This fact could probably be related with genetic factors, with more stable and homogeneous populations in the present study, and also imposed by more similar environmental conditions observed in the studied locations. It has been shown that the fatty acids composition varies slightly from region to region, related to the environmental condition, particularly with the lowest mean temperature observed during fruit growth [30,31]. 
Table 2. Fatty acids profile (\%) of oils extracted from oleaster (mean \pm standard deviation) collected from different geographical locations (Alijó, Moncorvo and Vila Nova de Foz Côa).

\begin{tabular}{|c|c|c|c|c|c|}
\hline Fatty Acid Profile (\%) & Olive Oil $^{1}$ & Alijó & Moncorvo & $\begin{array}{l}\text { Vila Nova de } \\
\text { Foz Côa }\end{array}$ & $\begin{array}{c}\text { One-Way ANOVA } \\
(p \text {-Value })^{2}\end{array}$ \\
\hline Myristic acid $\left(\mathrm{C}_{14: 0}\right)$ & $\leq 0.03$ & $0.02 \pm 0.01$ & $0.01 \pm 0.01$ & $0.02 \pm 0.01$ & 0.6629 \\
\hline Palmitic $\left(\mathrm{C}_{16: 0}\right)$ & $7.5-20.0$ & $14.24 \pm 2.22$ & $15.20 \pm 1.94$ & $14.68 \pm 2.45$ & 0.4755 \\
\hline Palmitoleic $\left(\mathrm{C}_{16: 1}\right)$ & $0.3-3.5$ & $2.54 \pm 1.38$ & $1.91 \pm 0.99$ & $2.03 \pm 0.87$ & 0.2374 \\
\hline Heptadecanoic $\left(C_{17: 0}\right)$ & $\leq 0.3$ & $0.09 \pm 0.03^{b}$ & $0.13 \pm 0.06^{\mathrm{a}}$ & $0.08 \pm 0.01^{b}$ & 0.0006 \\
\hline Heptadecenoic $\left(C_{17: 1}\right)$ & $\leq 0.3$ & $0.14 \pm 0.06^{b}$ & $0.19 \pm 0.09^{\mathrm{a}}$ & $0.10 \pm 0.01^{c}$ & 0.0010 \\
\hline Stearic $\left(\mathrm{C}_{18: 0}\right)$ & $0.5-5.0$ & $1.95 \pm 0.38^{b}$ & $2.02 \pm 0.18^{b}$ & $2.26 \pm 0.29^{a}$ & 0.0102 \\
\hline Oleic $\left(C_{18: 1}\right)$ & $55.0-83.0$ & $68.90 \pm 1.87$ & $70.60 \pm 1.82$ & $69.98 \pm 2.27$ & 0.0630 \\
\hline Linoleic $\left(\mathrm{C}_{18: 2}\right)$ & $2.5-21.0$ & $9.88 \pm 4.13$ & $7.87 \pm 1.32$ & $8.62 \pm 1.39$ & 0.1028 \\
\hline Linolenic $\left(C_{18: 3}\right)$ & $\leq 1.0$ & $1.06 \pm 0.04^{\mathrm{a}}$ & $0.93 \pm 0.12^{b}$ & $0.99 \pm 0.15^{b}$ & 0.0098 \\
\hline Arachidic $\left(C_{20: 0}\right)$ & $\leq 0.6$ & $0.37 \pm 0.02^{b}$ & $0.38 \pm 0.04^{\mathrm{a}, \mathrm{b}}$ & $0.39 \pm 0.02^{\mathrm{a}}$ & 0.0212 \\
\hline Eicosenoic $\left(C_{20: 1}\right)$ & $\leq 0.4$ & $0.29 \pm 0.02^{\mathrm{a}}$ & $0.27 \pm 0.04^{b}$ & $0.26 \pm 0.04^{b}$ & 0.0467 \\
\hline Behenic $\left(C_{22: 0}\right)$ & $\leq 0.2$ & $0.14 \pm 0.02$ & $0.15 \pm 0.02$ & $0.15 \pm 0.02$ & 0.0755 \\
\hline Lignoceric acid $\left(\mathrm{C}_{24: 0}\right)$ & $\leq 0.2$ & $0.07 \pm 0.02$ & $0.07 \pm 0.01$ & $0.07 \pm 0.03$ & 0.9286 \\
\hline$\sum$ SFA & N.D. ${ }^{2}$ & $16.9 \pm 1.91$ & $18 \pm 2.11$ & $17.69 \pm 2.26$ & 0.3210 \\
\hline$\sum$ MUFA & N.D. ${ }^{2}$ & $71.93 \pm 2.79$ & $73.01 \pm 0.98$ & $72.42 \pm 1.54$ & 0.2926 \\
\hline$\sum$ PUFA & N.D. ${ }^{2}$ & $10.94 \pm 4.17$ & $8.81 \pm 1.44$ & $9.61 \pm 1.49$ & 0.0867 \\
\hline
\end{tabular}

${ }^{1}$ Reference values for olive oil according to the Commission Regulation (EEC) 2568/91 of 11th July; ${ }^{2}$ not defined by Commission Regulation (EEC) 2568/91 of 11th July. Different lower case letters mean significant statistical differences between the geographical locations, at a 5\% significance level (one-way ANOVA followed by the Tukey's multi-comparison test).

Lower temperatures increase the amount of oleic acid with an increase of $1{ }^{\circ} \mathrm{C}$ causing up to $2 \%$ decrease on oleic amounts [32]. The geographical region under study (Northeastern Portugal) is colder than North Africa, probably contributing for the higher oleic acid and MUFA contents. Nevertheless, the climacteric conditions of the three locations of our work are very similar, the observed differences between populations probably being due to genetic factors.

\subsection{Tocopherols Composition}

Three tocopherols isoforms, namely $\alpha$-, $\beta$ - and $\gamma$-tocopherol, were quantified in the oleaster oils (Table 3). The most abundant compound was $\alpha$-tocopherol, ranging from 263 to $458 \mathrm{mg} / \mathrm{kg}$, with similar average amounts between the three studied populations (from 360.2 to $385.4 \mathrm{mg} / \mathrm{kg}$ of oil). However, the oils were significantly different ( $p$-value $<0.0010)$ in terms of $\gamma$-tocopherol content: the highest average was observed in the VNFC oils ( $76 \mathrm{mg} / \mathrm{kg}$ of oil) and the lowest in the Moncorvo population oils $(27 \mathrm{mg} / \mathrm{kg}$ of oil). $\beta$-Tocopherol contents were highly consistent, ranging from 5.5 to $6.5 \mathrm{mg} / \mathrm{kg}$ of oil. As can be seen from Table 3, the mean total amounts of tocopherols found in the oleaster oils from Alijó and VNFC populations (varying between 439.4 and $467.6 \mathrm{mg} / \mathrm{kg}$ of oil, respectively) were significantly higher than the amounts observed in oils from Moncorvo location ( $392.5 \mathrm{mg} / \mathrm{kg}$ of oil).

Table 3. Tocopherol contents ( $\mathrm{mg} / \mathrm{kg}$ of oil) of $\alpha$-. $\beta$ - and $\gamma$-tocopherols as well as Vitamin E (total tocopherol content) found in oils extracted from oleaster (mean \pm standard deviation) collected from different geographical locations (Alijó. Moncorvo and Vila Nova de Foz Côa).

\begin{tabular}{ccccc}
\hline $\begin{array}{c}\text { Tocopherol Contents } \\
(\mathbf{m g} / \mathbf{k g} \text { of oil) }\end{array}$ & Alijó & Moncorvo & $\begin{array}{c}\text { Vila Nova de Foz } \\
\text { Côa }\end{array}$ & $\begin{array}{c}\text { One-Way ANOVA } \\
(\boldsymbol{p} \text {-Value })^{\mathbf{1}}\end{array}$ \\
\hline$\alpha$-Tocopherol & $379.9 \pm 78.8$ & $360.2 \pm 60.1$ & $385.4 \pm 71.9$ & 0.5738 \\
$\beta$-Tocopherol & $6.5 \pm 3.8$ & $5.51 \pm 1.66$ & $6.26 \pm 1.12$ & 0.5062 \\
$\gamma^{-T o c o p h e r o l ~}$ & $53.0 \pm 20.8^{\mathrm{b}}$ & $26.84 \pm 13.90^{\mathrm{a}}$ & $75.95 \pm 33.30^{\mathrm{b}}$ & $<0.0001$ \\
$\Sigma$ Tocopherol & $439.4 \pm 84.1^{\mathrm{a}}$ & $392.5 \pm 59.8^{\mathrm{b}}$ & $467.6 \pm 99.6^{\mathrm{a}}$ & 0.0438 \\
\hline
\end{tabular}

${ }^{1}$ Different lower case letters mean significant statistical differences between the geographical locations, at a $5 \%$ significance level (one-way ANOVA followed by the Tukey's multi-comparison test). 
The tocopherol profile was similarly to that of olive oil, with $\alpha$-tocopherol representing more than $90 \%$ of the total tocopherol content [33]. The amounts quantified in the present work were much higher than those observed for oleaster oil from Algeria, which varied from 87 to $182 \mathrm{mg} / \mathrm{kg}$ of oil [7] and Turkey, with values lower than $40 \mathrm{mg} / \mathrm{kg}$ of oil [34] but were of the same order of magnitude of those reported by Baccouri [27], for seven populations from Tunisia (309.5-781.8 mg/kg of oil); and by Dabbou [12] that analysed two Tunisian samples and reported $\alpha$-tocopherol contents of 313-390 mg/kg of oil.

When comparing the results obtained in Table 3, for oleaster oils, with similar studies with olive oils obtained from cultivated varieties, it can be concluded that the oils from the studied oleaster samples presented, in general, higher values of $\alpha-, \beta$ - and $\gamma$-tocopherol contents, than the traditional ones $(12.2-630 \mathrm{mg} / \mathrm{k}$ of olive oil) [33,35]. Additionally, the amounts of $\gamma$-tocopherol observed in the present work were much higher, in some cases of five orders of magnitude, compared to those reported for varietal olive oils and also for oleaster oils from other regions. These differences could be attributed to genetic factors. In fact, Beltrán [33] and Baccouri [28] concluded that tocopherols are genetically regulated and are highly cultivar-dependent. Tocopherols play important roles, acting as antioxidants, and therefore protecting lipids in human body and stored oils from oxidation and, in this sense, oleaster oils could be foreseen as important sources of these bioactive compounds, with high oxidative stability.

\subsection{Sterols Composition}

The sterol composition found for the oleaster oils studied is given in Table 4. Among the sterols detected, $\beta$-sitosterol was the main sterol identified, followed by campesterol and stigmasterol. No differences were observed between populations for these main compounds. Nevertheless, the percentage of $\Delta$-7-estigmastenol $(0.76 \%)$ of oils from Alijó location was significantly higher ( $p$-value $=0.0384)$ than the values observed for oils of Moncorvo and VNFC populations (Table 4). The percentage of triterpenic alcohols from Alijó location $(0.47 \%)$ were significantly lower $(p$-value $=0.0265)$ than those observed for Moncorvo $(0.75 \%)$ and VNFC $(0.69 \%)$ populations. Additionally, total sterols were remarkably higher than the statutory minimum limit $(1000 \mathrm{mg} / \mathrm{kg}$ of oil) for olive oil and were significantly $(p$-value $=0.0124)$ higher for Alijó samples $(2199 \mathrm{mg} / \mathrm{kg})$ and lower for Moncorvo location $(1742 \mathrm{mg} / \mathrm{kg})$. Indeed, the contents of all sterols respects the established limits for olive oil with the exception of $\Delta$-7-estigmastenol (varying 0.61 to $0.76 \%$ ), slightly above the legal maximum $(0.5 \%)$ defined in the Commission Regulation (EEC 2568/91). It should be remarked that high levels of total sterols indicate that the oils are of high quality.

Table 4. Sterol compositions of oils extracted from oleaster (mean \pm standard deviation) collected from different geographical locations (Alijó. Moncorvo and Vila Nova de Foz Côa).

\begin{tabular}{cccccc}
\hline Sterols Composition & Olive Oil ${ }^{\mathbf{1}}$ & Alijó & Moncorvo & $\begin{array}{c}\text { Vila Nova de } \\
\text { Foz Côa }\end{array}$ & $\begin{array}{c}\text { One-Way ANOVA } \\
(p \text {-Value })^{2}\end{array}$ \\
\hline Cholesterol & $\leq 0.5 \%$ & $0.05 \pm 0.02^{\mathrm{b}}$ & $0.07 \pm 0.01^{\mathrm{a}}$ & $0.07 \pm 0.02^{\mathrm{a}}$ & 0.0040 \\
Brassicasterol & $\leq 0.1 \%$ & $0.03 \pm 0.00^{\mathrm{b}}$ & $0.04 \pm 0.01^{\mathrm{a}}$ & $0.04 \pm 0.01^{\mathrm{a}}$ & 0.0012 \\
Campesterol & $\leq 4.0 \%$ & $3.49 \pm 0.54$ & $3.69 \pm 0.30$ & $3.38 \pm 0.91$ & 0.3807 \\
Stigmasterol & $<\mathrm{camp}$ & $0.61 \pm 0.13$ & $0.79 \pm 0.60$ & $0.85 \pm 0.61$ & 0.3599 \\
$\beta$-Sitosterol apparent ${ }^{3}$ & $\geq 93.0 \%$ & $94.14 \pm 0.94$ & $94.05 \pm 0.99$ & $94.19 \pm 1.46$ & 0.9376 \\
$\Delta$-7-Stigmastenol & $\leq 0.5 \%$ & $0.76 \pm 0.22^{\mathrm{a}}$ & $0.61 \pm 0.13^{\mathrm{b}}$ & $0.63 \pm 0.17^{\mathrm{b}}$ & 0.0384 \\
Erythrodiol and uvaol & $\leq 4.5 \%$ & $0.47 \pm 0.21^{\mathrm{b}}$ & $0.75 \pm 0.39^{\mathrm{a}}$ & $0.69 \pm 0.27^{\mathrm{a}}$ & 0.0265 \\
Total Sterols & $\geq 1000 \mathrm{mg} / \mathrm{kg}$ & $2199 \pm 464^{\mathrm{a}}$ & $1742 \pm 280^{\mathrm{b}}$ & $1939 \pm 476^{\mathrm{a}, \mathrm{b}}$ & 0.0124 \\
\hline
\end{tabular}

${ }^{1}$ Reference values for olive oil according to the Commission Regulation (EEC) 2568/91 of 11th July. ${ }^{2}$ Different lower case letters mean significant statistical differences between the geographical locations, at a $5 \%$ significance level (one-way ANOVA followed by the Tukey's multi-comparison test). ${ }^{3} \beta$-sitosterol apparent $=$ sum of $\Delta$-5,23-estigmastadienol + clerosterol $+\beta$-sitosterol + sitostanol $+\Delta$-5-avenasterol $+\Delta$-5,24-estigmastadienol.

Additionally, low values of triterpenic alcohols indicate that the fruits are of good quality, and that good production practices were applied during the extraction process, namely a low extraction 
temperature and reduced time of malaxation. Furthermore, the sterolic fraction is a very useful parameter in the detection of adulterations, since it can be considered as a botanic origin marker [36]. In this case, the composition was very similar to olive oil once it is a variety of the same species $(O$. europaea subsp. europaea var. sylvestris) and oleaster oil is a rich source of phytosterols. This fact is of major relevance, since several biological activities have been attributed to phytosterols, mainly those related with the reduction of cholesterol absorption levels in the blood, sometimes being used in the treatment of hypercholesterolemia [5]. The amounts of total sterols quantified in the oleaster oils were in accordance with those reported in other studies, namely by Hannachi [5], Baccouri [11] and Mohamed [36], with the exception of the levels of $\beta$-sitosterol, which could be related with the analytical methodologies used. On the other hand, once sterol content is influenced by several factors, such as climate, cultivar, geographical location and production practices [37] these aspects may also justify the differences observed in the amount of sterols.

\subsection{Phenolic Compounds}

Fourteen phenolic compounds were detected and quantified in the oleaster oils obtained from the three different populations. The identified phenolic compounds belong to five phenolic groups, namely, phenolic alcohols, flavonoids, secoiridoids aglycons, dihydroxybenzoic acids derivatives and phenolic acids (Table 5). The group of secoiridoids aglycons was the one present in greater quantities, imposed by the high ligstroside derivatives quantity that ranged from $271 \mathrm{mg} / \mathrm{kg}$ (Moncorvo location) and $359 \mathrm{mg} / \mathrm{kg}$ of oil (VNFC location), with statistical differences between both locations, and oleuropein aglycon (and derivatives) prevalence, with values between $227 \mathrm{mg} / \mathrm{kg}$ (Alijó location) and $261 \mathrm{mg} / \mathrm{kg}$ of oil (VNFC location), without statistical differences between locations.

Table 5. Phenolic composition ( $\mathrm{mg} / \mathrm{kg}$ of oil) of oils extracted from oleaster (mean \pm standard deviation) collected from different geographical locations (Alijó. Moncorvo and Vila Nova de Foz Côa). Different lower case letters mean significant statistical differences at a 5\% significance level (one-way ANOVA followed by the Tukey's multi-comparison test).

\begin{tabular}{|c|c|c|c|c|}
\hline Phenolic Compounds & Alijó & Moncorvo & Vila Nova de Foz Côa & $\begin{array}{l}\text { One-Way ANOVA } \\
\quad(p \text {-Value })^{1}\end{array}$ \\
\hline \multicolumn{5}{|l|}{ Phenolic alcohols } \\
\hline Hydroxytyrosol (3.4-DHPEA) & $3.3 \pm 0.5$ & $4.0 \pm 0.8$ & $4.3 \pm 3.1$ & 0.2997 \\
\hline Tyrosol $(p$-HPEA) & $8.4 \pm 5.6$ & $8.0 \pm 6.1$ & $9.34 \pm 7.2$ & 0.8271 \\
\hline Hydroxytyrosol acetate & $0.7 \pm 0.3^{\mathrm{a}}$ & $0.3 \pm 0.2^{b}$ & $0.3 \pm 0.1^{b}$ & $<0.0001$ \\
\hline \multicolumn{5}{|l|}{ Flavonoids } \\
\hline Luteolin & $7.4 \pm 5.5$ & $8.3 \pm 0.6$ & $11.8 \pm 12.5$ & 0.2687 \\
\hline Apigenin & $9.4 \pm 5.5$ & $12.0 \pm 2.5$ & $13.2 \pm 5.5$ & 0.0787 \\
\hline Methyl-Luteolin & $0.6 \pm 0.4$ & $0.6 \pm 0.6$ & $0.5 \pm 0.5$ & 0.5789 \\
\hline \multicolumn{5}{|l|}{ Secoiridoids } \\
\hline Oleuropein aglycon (and derivatives) & $226.3 \pm 55.0$ & $233.3 \pm 108.3$ & $260.6 \pm 81.8$ & 0.4845 \\
\hline Oleuropein & $33.6 \pm 17.0^{\mathrm{b}}$ & $44.4 \pm 24.0^{\mathrm{a}, \mathrm{b}}$ & $58.9 \pm 29.2^{\mathrm{a}}$ & 0.0165 \\
\hline $\begin{array}{l}\text { Ligstroside aglycon and derivatives } \\
\text { Dihydroxybenzoic derivatives }\end{array}$ & $287.5 \pm 83.8^{a, b}$ & $270.6 \pm 95.9^{b}$ & $358.8 \pm 107.8^{a}$ & 0.0304 \\
\hline Vanillin & $1.1 \pm 0.6^{\mathrm{a}}$ & $0.5 \pm 0.3^{b}$ & $0.6 \pm 0.5^{b}$ & 0.0077 \\
\hline \multicolumn{5}{|l|}{ Phenolic acids } \\
\hline$p$-Coumaric acid & $5.3 \pm 2.0^{\mathrm{b}}$ & $10.7 \pm 8.8^{a}$ & $6.9 \pm 3.2^{a, b}$ & 0.0241 \\
\hline$o$-Coumaric acid & $0.4 \pm 0.1$ & $0.6 \pm 1.0$ & $0.2 \pm 0.1$ & 0.1114 \\
\hline Cinamic acid & $14.9 \pm 7.5^{b}$ & $14.7 \pm 4.8^{b}$ & $24.0 \pm 8.7^{\mathrm{a}}$ & 0.0007 \\
\hline Ferulic acid & $0.6 \pm 0.2$ & $0.6 \pm 0.4$ & $0.4 \pm 0.2$ & 0.0932 \\
\hline$\sum$ Phenols & $602.7 \pm 151.9$ & $612.0 \pm 216.8$ & $751.9 \pm 221.5$ & 0.0705 \\
\hline
\end{tabular}

${ }^{1}$ Different lower case letters mean significant statistical differences between the geographical locations, at a $5 \%$ significance level (one-way ANOVA followed by the Tukey's multi-comparison test). 
Oleuropein aglycon and derivative forms were the second most represented group of compounds. The third most abundant compounds, oleuropein, showed statistically higher contents $(p$-value $=0.0165)$ in the oils from VNFC location $(58.9 \mathrm{mg} / \mathrm{kg}$ of oil) than those quantified in the oils from Alijó location (33.6 mg/kg of oil) (Table 5). In the group of phenolic alcohols, tyrosol ( $p$-HPEA) ranged from $8.0 \mathrm{mg} / \mathrm{kg}$ of oil (Moncorvo location) and $9.4 \mathrm{mg} / \mathrm{kg}$ of oil (VNFC location). Together with hydroxytyrosol acetate, these were the only significantly different phenolic alcohols between populations, with highest values observed for Alijó location. Among the identified flavonoids, apigenin (9.4-13.2 mg/kg of oil) showed higher values compared to luteolin (7.4-11.8 mg/kg of oil) and methyl-luteolin, with statistical differences between oleaster populations. Similarly, luteolin and apigenin were the major flavonoids found in oleaster oils from Algeria [7]. In the group of dihydroxybenzoic acid derivatives only vanillin was found, in significantly higher amounts for oils produced from Alijó population $(1.06 \mathrm{mg} / \mathrm{kg}$ of oil). Four phenolic acids were identified, namely $p$-coumaric acid, o-coumaric acid, cinnamic acid and ferulic acid. Cinnamic acid was the most abundant phenolic acid, and its content was significantly higher in oils obtained at VNFC $(24.0 \mathrm{mg} / \mathrm{kg}$ of oil), whereas, $p$-coumaric acid was significantly higher $(p$-value $=0.0241)$ in Moncorvo oleaster oils $(10.7 \mathrm{mg} / \mathrm{kg}$ of oil). In general, the obtained results are in agreement with those obtained for Algerian oleaster oils [7], and also similar to the reported by Peres [38] for cultivated traditional Portuguese cultivars (cvs. Galega Vulgar and Cobrançosa). Oleaster oils possess a considerable amount of phenolic compounds, with the mean contents in the range of 600 to $750 \mathrm{mg} / \mathrm{kg}$ of oil. Again, the obtained values were higher to those observed by Bouarroudj [7] for Algerian oleaster oils, and for Portuguese-cultivated olive varieties [38]. These findings are quite relevant since different works previously demonstrated the importance of phenolic compounds on the sensory characteristics, resistance to oxidation and positive health effects of olive oils, being in this case oleaster oils also a good source of these compounds.

\subsection{Oleaster Oils Discrimination According to the Geographical Location Based on Their Physicochemical Profiles}

As previously discussed, the Portuguese oleaster oils studied showed physicochemical profiles (fatty acids, tocopherols, sterols and phenolic compounds) with similarities with those of oleaster oils from other countries (e.g., Algeria and Tunisia), as well as of cultivated olive trees (from Portugal and other countries). However, as also pointed out, for some chemical minor compounds (i.e., less abundant ones), significant statistical differences were detected among the three populations evaluated. Thus, LDA coupled with the SA algorithm (LDA-SA) was implemented to identify the chemical compounds that could be further used as chemical markers for each population studied (i.e., Alijó, Moncorvo and VNFC locations) allowing discriminating the oleaster oils according to the geographical origin of the wild olive trees (Figure 1).

The results show that a LDA-SA model with two linear discriminant functions (explaining $99.72 \%$ and $0.28 \%$, respectively) could be established based on the contents of five chemical compounds (i.e., eicosenoic fatty acid; SFA; triterpenic alcohols (erytrodiol + uval); hydroxytyrosol acetate; and cinnamic acid). The established model enabled the correct classification of $100 \%$ of the oils according to the location for the original grouped data. Additionally, for the LOO-CV procedure, a predicted correct classification rate of $100 \%$ was also obtained. These results clearly illustrated that, besides their relevance for health or sensory positive sensations, these chemical compounds and their contents may be further used as chemical location markers for oleaster oils. 


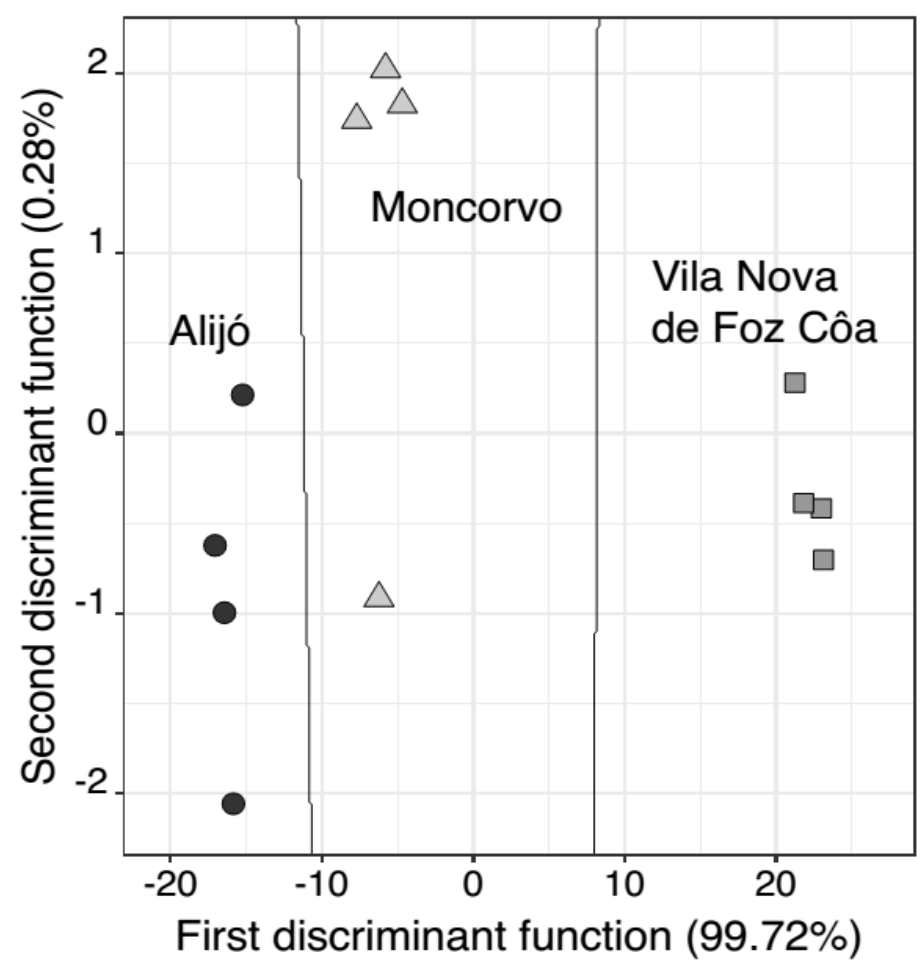

Figure 1. Discrimination of oleaster oils according to three geographical origins (• Alijó; $\mathbf{\Delta}$ Moncorvo; or, Vila Nova de Foz Côa) using a LDA-SA model based on the contents of eicosenoic fatty acid; SFA; erythrodiol and uvaol; hydroxytyrosol acetate; and, cinnamic acid. The full lines represent the boundary lines based on the posterior probabilities calculated for each class membership.

\section{Conclusions}

Within the present work, we intended to characterize the oleaster oils obtained from three distinct locations in Northeastern Portugal. The results showed that the different populations presented some morphological differences but a very similar oil composition, with only slight variations in some fatty acids, tocopherols, sterols and phenolic compounds that allowed discriminating the oils according to the location of origin. Fatty acid composition revealed that oleic acid (68.9-70.6\%), followed by palmitic (14.2-14.7\%) and linoleic acid (7.87-9.88\%), were the most abundant, similarly to olive oils. $\alpha$-Tocopherol represented more than $90 \%$ of the tocopherols detected, with total tocopherol values ranging from 263 to $503 \mathrm{mg} / \mathrm{kg}$ of oil. $\beta$-Sitosterol was the major sterol observed, and total sterol values varied from 1742 to $2198 \mathrm{mg} / \mathrm{kg}$ of oil, again within olive oil regulation. Fourteen phenolic compounds from five families (dihydroxybenzoic derivatives, flavonoids, phenolic acids, phenolic alcohols, and secoiridoids,) were identified and quantified. Ligstroside derivatives (271-359 mg/kg of oil) and oleuropein aglycon and derivatives $(227-261 \mathrm{mg} / \mathrm{kg}$ of oil) were the most abundant ones, which is of major relevance from a health point of view. Thus, it could be concluded that oleaster oils presented a chemical profile very similar to olive oil, largely enriched in compounds such as tocopherols, sterols and phenolics. Furthermore, it was found that the region is an important factor in the chemical composition of the studied oils. Although the profile is similar across all of them, the composition varied, with some being richer in antioxidant compounds than others, particularly the VNFC population, despite having the shorter fruits in the study. The rich composition of oleaster oils indicates that the characterized populations could be included in breeding programs to produce olive oils rich in bioactive compounds. Nevertheless, other aspects should be considered, such as fruit yield in oil, fruit size, susceptibility to pests and diseases, and suitability to mechanization. On the other hand, considering the market search for sensory and chemical differentiated products, the production of oleaster oils for commercial purposes could be envisaged. 
Author Contributions: Conceptualization: N.R., P.B. and J.A.P.; methodology: N.R., T.P., S.C. and A.M.P.; investigation: all authors; resources: S.C. and J.A.P.; writing-original draft preparation: N.R., S.C., A.M.P., P.B. and J.A.P.; writing-review and editing: S.C., A.M.P., P.B. and J.A.P. All authors have read and agreed to the published version of the manuscript.

Funding: The authors are grateful to the Foundation for Science and Technology (FCT, Portugal) for financial support by national funds FCT/MCTES to CIMO (UIDB/00690/2020), and to REQUIMTE (NORTE- 01- 0145FEDER-LAQV (UIDB/50006/2020). This work was also supported by PRODER project OliveOld-Identificação e caraterização de oliveiras centenárias para obtenção de produtos diferenciados" no. 53988. Nuno Rodrigues thanks to National funding by FCT-Foundation for Science and Technology, P.I., through the institutional scientific employment program-contract.

Conflicts of Interest: The authors declare no conflict of interest.

\section{References}

1. Breton, C.; Guerin, C.; Ducatillon, J.; Médail, F.; Kull, C.; Bervillé, A. Taming the wild and 'wilding' the tame: Tree breeding and dispersal in Australia and the Mediterranean. Plant Sci. 2008, 175, 197-205. [CrossRef]

2. Breton, C.; Terral, J.F.; Pinatel, C.; Médail, F.; Bonhomme, F.; Bervillé, A. The origins of the domestication of the olive tree. Comptes Rendus Biol. 2009, 332, 1059-1064. [CrossRef] [PubMed]

3. Besnard, G.; Bervillé, A. Multiple origins for Mediterranean olive (Olea europaea L. ssp. europaea) based upon mitochondrial DNA polymorphisms. Comptes Rendus de l'Académie des Sciences-Series III-Sciences de la Vie 2000, 323, 173-181. [CrossRef]

4. Breton, C.; Médail, F.; Pinatel, C.; Bervillé, A. De l'olivier à l'oléastre: Origine et domestication de l'Olea europaea L. dans le Bassin méditerranéen. Cah. Agric. 2006, 15, 329-336.

5. Hannachi, H.; Nasri, N.; El Falleh, W.; Tlili, N.; Ferchichi, A.; Msallem, M. Fatty acids, sterols, polyphenols, and chlorophylls of olive oils obtained from Tunisia $n$ wild olive trees (Olea europaea L. var. sylvestris). Int. J. Food Prop. 2013, 16, 1271-1283. [CrossRef]

6. Terral, J.F.; Arnold-Simard, G. Beginnings of olive cultivation in relation to Holocene bioclimatic changes. Quat. Res. 1996, 46, 176-185. [CrossRef]

7. Bouarroudj, K.; Tamendjari, A.; Larbat, R. Quality, composition and antioxidant activity of Algerian wild olive (Olea europaea L. subsp. oleaster) oil. Ind. Crop. Prod. 2016, 83, 484-491. [CrossRef]

8. Tanjour, Z. An evaluation of physicochemical parameters of some wild olive oil varieties in Syrian Coastal Territory. J. Pharmacogn. Phytochem. 2014, 2, 146-153.

9. Baccouri, B.; Guerfel, M.; Zarrouk, W.; Taamalli, W.; Daoud, D.; Zarrouk, M. Wild olive (Olea europaea L.) selection for quality oil production. J. Food Biochem. 2010, 35, 161-176. [CrossRef]

10. Rubio de Casas, R.; Besnard, G.; Schönswetter, P.; Balaguer, L.; Vargas, P. Extensive gene flow blurs phylogeographic but not phylogenetic signal in Olea europaea L. Theor. Appl. Genet. 2006, 113, 575-583. [CrossRef]

11. Baccouri, B.; Manai, H.; Casas, J.S.; Osorio, E.; Zarrouk, M. Tunisian wild olive (Olea europaea L. subsp. oleaster) oils: Sterolic and triterpenic dialcohol compounds. Ind. Crop. Prod. 2018, 120, 11-15. [CrossRef]

12. Dabbou, S.; Dabbou, S.; Selvagginib, R.; Urbanib, S.; Taticchib, A.; Servili, M.; Hammami, M. Comparison of the chemical composition and the organoleptic profile of virgin olive oil from two wild and two cultivated Tunisian Olea Europaea. Chem. Biodivers. 2011, 8, 189-202. [CrossRef]

13. UPOV-International Union for the Protection of New Varieties of Plants. Guidelines for the Conduct of Tests for Distinctness, Uniformity and Stability. 2011. Available online: https://www.upov.int/upov_collection/en/ (accessed on 10 July 2020).

14. Commission Regulation. (ECC) no 2568/91: On the characteristics of olive oil and olive-pomace oil and on the relevant methods of analysis. Off. J. Eur. Union 1991, 248, 1-83.

15. ISO 9936. Animal and Vegetable Fats and Oils-Determination of Tocopherol and Tocotrienol Contents by High-Performance Liquid Chromatography, 2nd ed. 2006. Available online: https://www.iso.org/standard/ 38942.html (accessed on 21 June 2020).

16. Rodrigues, N.; Malheiro, R.; Casal, S.; Asensio-S.-Manzanera, M.C.; Bento, A.; Pereira, J.A. Influence of spike lavender (Lavandula latifolia Med.) essential oil in the quality, stability and composition of soybean oil during microwave heating. Food Chem. Toxicol. 2012, 50, 2894-2901. [CrossRef] [PubMed] 
17. IOC, International Olive Council. Chemical Analysis of Olive Oils, Method-Determination of Biophenols in Olive Oil by HPLC, COI/T.20/Doc No 29/Rev.1 2017. Available online: https://www.internationaloliveoil. org/what-we-do/chemistry-standardisation-unit/standards-and-methods/ (accessed on 3 February 2020).

18. Celano, R.; Piccinelli, A.L.; Pugliese, A.; Carabetta, S.; di Sanzo, R.; Rastrelli, L.; Russo, M. Insights into the Analysis of Phenolic Secoiridoids in Extra Virgin Olive Oil. J. Agric. Food Chem. 2018, 66, 6053-6063. [CrossRef]

19. Suárez, M.; Macià, A.; Romero, M.P.; Motilva, M.J. Improved liquid chromatography tandem mass spectrometry method for the determination of phenolic compounds in virgin olive oil. J. Chromatogr. A 2008, 1214, 90-99. [CrossRef]

20. Torre-Carbot, K.; Jauregui, O.; Gimeno, E.; Castellote, A.I.; Lamuela-Raventós, R.M.; López-Sabater, M.C. Characterization and Quantification of Phenolic Compounds in Olive Oils by Solid-Phase Extraction, HPLC-DAD, and HPLC-MS/MS. J. Agric. Food Chem. 2005, 53, 4331-4340. [CrossRef]

21. Bishop, C.M. Pattern Recognition and Machine Learning, 1st ed.; Springer: New York, NY, USA, 2006.

22. Cadima, J.; Cerdeira, J.O.; Minhoto, M. Computational aspects of algorithms for variable selection in the context of principal components. Comput. Stat. Data Anal. 2004, 47, 225-236. [CrossRef]

23. Cadima, J.; Cerdeira, J.O.; Silva, P.D.; Minhoto, M. The Subselect R Package. 2012. Available online: http://cran.rproject.org/web/packages/subselect/vignettes/subselect.pdf (accessed on 15 February 2016).

24. Kuhn, M.; Johnson, K. Applied Predictive Modeling; Springer Science Business Media: New York, NY, USA, 2013.

25. Venables, W.N.; Ripley, B.D. Modern Applied Statistics with S (Statistics and Computing), 4th ed.; Springer: New York, NY, USA, 2002.

26. Peres, A.M.; Baptista, P.; Malheiro, R.; Dias, L.G.; Bento, A.; Pereira, J.A. Chemometric classification of several olive cultivars from Trás-os-Montes region (northeast of Portugal) using artificial neural networks. Chemom. Intell. Lab. 2011, 105, 65-73. [CrossRef]

27. Laaribi, I.; Gouta, H.; Ayachi, M.M.; Labidi, F.; Mars, M. Combination of morphological and molecular markers for the characterization of ancient native olive accessions in Central-Eastern Tunisia. Comptes Rendus Biol. 2017, 340, 287-297. [CrossRef]

28. Baccouri, B.; Zarrouk, W.; Baccouri, O.; Guerfel, M.; Nouairi, I.; Krichene, D.; Daoud, D.; Zarrouk, M. Composition, quality and oxidative stability of virgin olive oils from some selected wild olives (Olea europaea L. subsp. oleaster). Grasas Aceites 2008, 59, 346-351. [CrossRef]

29. Gonçalves, F.M.; Malheiro, R.; Casal, S.; Torres, L.M.; Pereira, J.A. Influence of fruit traits on oviposition preference of the olive fly, Bactrocera oleae (Rossi) (Diptera: Tephritidae), on three portuguese olive varieties (Cobrançosa, Madural and Verdeal Transmontana). Sci. Hortic. 2012, 145, 127-135. [CrossRef]

30. Ceci, L.N.; Mattar, S.B.; Carelli, A.A. Chemical quality and oxidative stability of extra virgin olive oils from San Juan province (Argentina). Food Res. Int. 2017, 100, 764-770. [CrossRef] [PubMed]

31. Tena, N.; Aparicio, R.; García-González, D.L. Virgin olive oil stability study by mesh cell-FTIR spectroscopy. Talanta 2017, 167, 453-461. [CrossRef]

32. Rondanini, D.P.; Castro, D.N.; Searles, P.S.; Rousseaux, M.C. Fatty acid profiles of varietal virgin olive oils (Olea europaea L.) from mature orchards in warm arid valleys of Northwestern Argentina (La Rioja). Grasas y Aceites 2011, 62, 399-409. [CrossRef]

33. Beltrán, G.; Jiménez, A.; Del Rio, C.; Sánchez, S.; Martínez, L.; Uceda, M.; Aguilera, M.P. Variability of vitamin E in virgin olive oil by agronomical and genetic factors. J. Food Compos. Anal. 2010, 23, 633-639. [CrossRef]

34. Baldioli, M.; Servili, M.; Perreti, G.; Montedoro, G.F. Antioxidant activity of tocopherols and phenolic compounds of virgin olive oil. J. Am. Oil Chem. Soc. 1996, 73, 1589-1593. [CrossRef]

35. Tura, D.; Gigliotti, C.; Pedo, S.; Failla, O.; Bassi, D.; Serraiocco, A. Influence of cultivar and site of cultivation on levels of lipophilic and hydrophilic antioxidants in virgin olive oils (Olea europea L.) and correlations with oxidative stability. Sci. Hortic. 2007, 112, 108-119. [CrossRef]

36. Mohamed, M.B.; Rocchetti, G.; Montesano, D.; Ali, S.B.; Guasmi, F.; Grati-Kamoun, N.; Lucini, L. Discrimination of Tunisian and Italian extra-virgin olive oils according to their phenolic and sterolic fingerprints. Food Res. Int. 2018, 106, 920-927. [CrossRef] 
37. Lerma-García, M.J.; Simó-Alfonso, E.F.; Méndez, A.; Lliberia, J.L.; Herrero-Martínez, J.M. Classification of extra virgin olive oils according to their genetic variety using linear discriminant analysis of sterol profiles established by ultra-performance liquid chromatography with mass spectrometry detection. Food Res. Int. 2011, 44, 103-108. [CrossRef]

38. Peres, F.; Martins, L.L.; Mourato, M.; Vitorino, C.; Antunes, P.; Ferreira-Dias, S. Phenolic compounds of 'Galega Vulgar' and 'Cobrançosa' olive oils along early ripening stages. Food Chem. 2016, 21, 51-58. [CrossRef] [PubMed]

(C) 2020 by the authors. Licensee MDPI, Basel, Switzerland. This article is an open access article distributed under the terms and conditions of the Creative Commons Attribution (CC BY) license (http://creativecommons.org/licenses/by/4.0/). 